\title{
Meningkatkan Potensi Desa dari Hasil Laut di Desa Keutapang Mameh, Idi Rayeuk, Aceh Timur (KKN Tematik Unsam 2021)
}

\section{Robinsar Fiezhardo Manalu*1, Ihsan Nofriandi ${ }^{2}$, Cut Azura Izatul Nufus ${ }^{3}$, Elisa Widiharti $^{4}$, Ellida Novita Lydia ${ }^{5}$, Nina Fahriana ${ }^{6}$}

\author{
1,2,3,4,5,6Fakultas Teknik, Universitas Samudra, Indonesia \\ *e-mail: binsarmanalu93@gmail.com ${ }^{1}$ ihsan2015h@gmail.com ${ }^{2}$ icoet23102000@gmail.com ${ }^{3}$, \\ elisawidiharti2526@gmail.com ${ }^{4}$
}

\begin{abstract}
Abstrak
Hasil laut merupakan sumber daya alam yang sangat berharga untuk manusia, khususnya desa Keutapang Mameh yang langsung berada di kawasan pesisir. Desa Keutapang Mameh merupakan salah satu desa di kecamatan Idi Rayeuk, Aceh Timur, Provinsi Aceh, Indonesia yang memiliki berbagai macam potensi yang dapat dikembangkan dari hasil laut. Melalui program Kuliah Kerja Nyata (KKN) Tematik Universitas Samudra 2021, mahasiswa mengabdikan dirinya kepada masyarakat agar potensi yang dimiliki dapat dikembangkan dengan optimal dengan metode sosialisasi dan pelatihan. Antusiasme masyarakat dalam kegiatan ini merupakan pencapaian utama yang diterima oleh mahasiswa. Program pengabdian masyarakat yang dilakukan oleh mahasiswa merupakan wujud dari TriDharma Perguruan Tinggi, dimana mahasiswa dapat belajar untuk mengidentifikasi masalah dan menemukan solusinya.
\end{abstract}

Kata kunci: Desa Keutapang Mameh, KKN Tematik, Potensi Hasil Laut, Universitas Samudra

\begin{abstract}
Marine products are natural resources that are very valuable for humans, especially the village of Keutapang Mameh which is directly located in the coastal area. Keutapang Mameh Village is one of the villages in Idi Rayeuk sub-district, East Aceh, Aceh Province, Indonesia which has various kinds of potential that can be developed from marine products. Through the 2021 Ocean University Thematic Real Work Lecture (KKN) program, students devote themselves to the community so that their potential can be developed optimally with socialization and training methods. The enthusiasm of the community in this activity is the main achievement received by students. The community service program carried out by students is a manifestation of the Tri Dharma of Higher Education, where students can learn to identify problems and find solutions.
\end{abstract}

Keywords: Keutapang Mameh Village, Resources Of The Ocean, Samudra University, Thematic Community Service Program

\section{PENDAHULUAN}

Desa Keutapang Mameh adalah salah satu desa yang ada di Kecamatan Idi Rayeuk, Aceh Timur, Provinsi Aceh, Indonesia. Desa ini berada di pesisir pantai dan memiliki potensi perikanan laut yang cukup besar. Secara geografis Desa ini merupakan wilayah yang berada di daerah dataran rendah. Kecamatan Idi Rayeuk sendiri terdiri dari 1 kelurahan 35 Desa, jarak Keutapang Mameh dengan Kecamatan Idi Rayeuk yaitu $2 \mathrm{Km}$ dan jarak Keutapang Mameh terhadap ibu kota Kabupaten yaitu $2 \mathrm{Km}$. Desa Keutapang Mameh merupakan desa yang sebelah barat berbatasan dengan Desa Ulee blang, sebelah timur berbatasan d engan Desa Kuala Idi, sebelah utara berbatasan dengan Selat Malaka dan sebelah selatan berbatasan dengan Tanjong Kapai.

Desa Keutapang Mameh, Kecamatan Idi Rayeuk, Kabupaten Aceh Timur mempunyai penduduk berjumlah 1703. Berdasarkan data ini, tentunya pembangunan dari segi Sumber Daya Manusia perlu ditingkatkan melalui program Pemberdayaan Masyarakat, agar kualitas Sumber Daya Manusia dan Sumber Daya Alam bisa membangun Desa keutapang mameh semakin meningkat.

Apabila ditinjau dari segi pekerjaan, umumnya masyarakat desa keutapang Mameh 
bekerja sebagai nelayan, sehingga tidak heran apabila di Desa Keutapang Mameh terdapat orang yang memiliki perahu pribadi dan membuka lapangan pekerjaan untuk para pengangguran agar menangkap hasil laut. Disamping itu, kehidupan masyarakat di Desa Keutapang Mameh sangat kental dengan adat isitiadat dan buadaya yang ada. Kode Wilayah Kemendagri untuk desa ini yaitu 11.03.03.2011.

Di desa keutapang mameh merupakan desa yang mayoritas penduduknya nelayan dan petani tambak sehingga dapat memproduksi ikan asin yang dapat di olah sebagai bahan baku pembuatan kerupuk ikan asin. Salah satu bahan baku kerupuk ikan asin adalah Ikan Kambingkambing (Abalistes stellaris). Ikan Kambing-kambing adalah ikan laut yang belum dimanfaatkan secara optimal. Untuk menambah nilai tambah dari ikan tersebut maka diolah menjadi kerupuk ikan asin.

Perairan laut Aceh yang berada di antara Selat Malaka (pesisir timur) dan Samudera Hindia (pesisir barat), menempatkan daerah ini berhadapan langsung dengan negara-negara di kawasan Asia Tenggara dan Asia Selatan. Laut Aceh merupakan asset besar yang berperan sebagai sumber kekayaan alam, sumber energi, sumber bahan makanan, media lintas laut antar pulau, kawasan perdagangan, dan wilayah pertahanan keamanan.

Diakui bahwa perhatian masyarakat Aceh terhadap potensi wilayah lautnya semakin berkembang. Kecendrungan ini dipengaruhi oleh perkembangan pembangunan yang dinamis yang mengakibatkan semakin terbatasnya potensi sumber daya di darat. Pengaruh lainnya adalah perkembangan kemaritiman secara nasional sehingga memberikan kemudahan dalam pemanfaatan dan pengelolaan sumber daya laut. (Daudy, 2015)

Upaya meningkatkan pendapatan yang pada akhirnya meningkatkan kesejahteraan masyarakat merupakan salah satu tujuan pembangunan. Banyak cara yang dilakukan dalam memacu pembangunan, salah satunya dilakukan dengan melakukan pengembangan sumberdaya manusia baik sebagai pelaku maupun objek dari pembangunan tersebut yang selalu kita dengan dengan istilah pemberdayaan masyarakat. (Margolang, 2018)

Adapun tujuan dari Kegiatan ini adalah sebagai berikut.

a. Meningkatkan Hasil Laut di Desa Keutapang Mameh Kecamatan Idi Rayeuk Untuk Peningkatan Ekonomi Masyarakat.

b. Memberdayakan Masyarakat Untuk Pemanfaatan Hasil Limbah Laut Yang Ada di Desa Keutapang Mameh.

c. Meningkatkan Masyarakat Desa Keutapang Mameh Dalam Pemanfaatan Limbah Laut.

\section{METODE}

\subsection{Lokasi dan Waktu Pengabdian}

Lokasi kegiatan ini dilaksanakan di Idi Rayeuk, Desa Keutapang Mameh, Kecamatan Idi Rayeuk, Kabupaten Aceh Timur, Kota Idi. Pemilihan lokasi ini didasarkan aturan yang disampaikan oleh pihak Universitas Samudra bahwa KKN Tematik ini dilakukan pada Desa Keutapang Mameh, Kecamatan Idi Rayeuk. KKN dilaksanakan pada 29 Juli- 31 Agustus 2021.

\subsection{Khalayak Sasaran}

Seluruh masyarakat desa merupakan sasaran kegiatan KKN Tematik ini, yang meliputi: Perangkat desa, Petani Tambak, Ibu-ibu PKK, dan Pelajar.

\subsection{Metode Pelaksanaan}

Dalam kegiatan KKN Tematik ini terdapat beberapa program sehingga dibagi menjadi beberapa bagian. Program - program tersebut digagas dan direncanakan oleh masing -masing mahasiswa dengan menerapkan bidang dan keilmuwan mahasiswa sesuai dengan program studi masing - masing. Program - program yang telah disusun diimplementasikan dengan metode sosialisasi dan penyuluhan kepada masyarakat desa. 
Tabel 1. Program Kerja

\begin{tabular}{|c|c|c|}
\hline No & Program & Kegiatan \\
\hline \multirow[t]{3}{*}{1} & $\begin{array}{l}\text { Optimalisasi } \\
\text { pemanfaatan hasil }\end{array}$ & $\begin{array}{l}\text { a. Sosialisasi menumbuhkan plankton di tambak ikan sebagai } \\
\text { pakan alami. }\end{array}$ \\
\hline & laut untuk & b. Sosialisasi pengawetan ikan secara kimiawi dengan garam. \\
\hline & $\begin{array}{l}\text { peningkatan } \\
\text { ekonomi }\end{array}$ & c. Pelatihan pembuatan kerupuk ikan asin kepada masyarakat. \\
\hline \multirow[t]{2}{*}{2} & $\begin{array}{l}\text { Pengembangan } \\
\text { sarana dan }\end{array}$ & $\begin{array}{l}\text { a. Perencanaan rehabilitasi saluran irigasi tambak masyarakat } \\
\text { desa. }\end{array}$ \\
\hline & prasaranan desa & $\begin{array}{l}\text { b. Sosialisasi pembuatan alat pengolahan air baku sederhana. } \\
\text { c. Pembuatan website resmi desa. }\end{array}$ \\
\hline
\end{tabular}

1. Pembuatan kerupuk ikan asin

Kerupuk adalah makanan ringan yang dibuat dari adonan tepung tapioka yang dicampurkan bahan perasa seperti udang dan ikan. Kerupuk juga jenis makanan kering yang sangat popular di Indonesia, mengandung pati cukup tinggi, serta dibuat dari bahan dasar tepung tapioka dan bisa menjadikan lauk sederhana untuk makanan, karena rasanya yang gurih dan enak yang dapat menambah selera makan. Kerupuk Ikan Asin menggunakan Ikan Asin Kambing-kambing yang tidak layak jual karena patah.

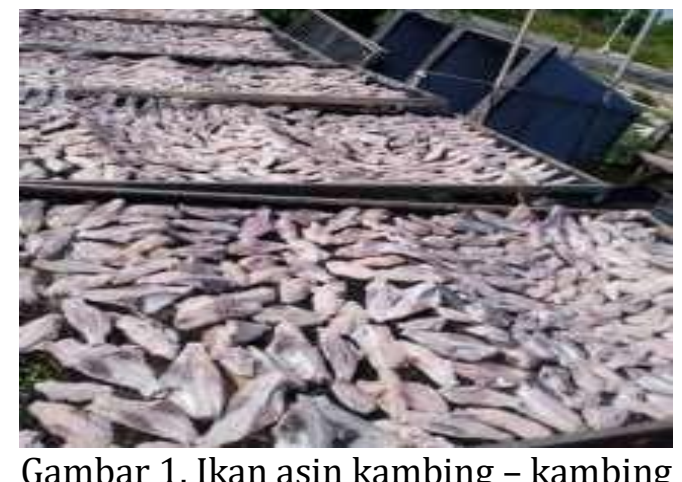

\section{Sosialisasi cara menumbuhkan plankton ditambak ikan}

Budidaya perairan merupakan salah satu teknologi yang telah dikembangkan dan dapat menjadi salah satu strategi dalam memenuhi kebutuhan pangan. Manfaat plankton pada pengelolaan tambak udang dan ikan intensif yaitu saat kekeruhan karena plankton dengan nilai daya cerah perairan antara 30-40 cm justru diperlukan dan pertumbuhan plankton yang baik ditandai oleh berubahnya warna air tambak dari coklat hingga hijau muda mutlah dipertahankan karena satu budidaya plankton dikenal dengan EM4. EM4 (Effective Microorganisms) berupa cairan berwarna kecoklatan dan berbau manis asam (segar). Kegiatan sosialisasi kepada masyarakat Desa Keutapang Mameh tentang Budidaya Plankton di Tambak dilaksanakan pada hari kelima KKN Tematik.

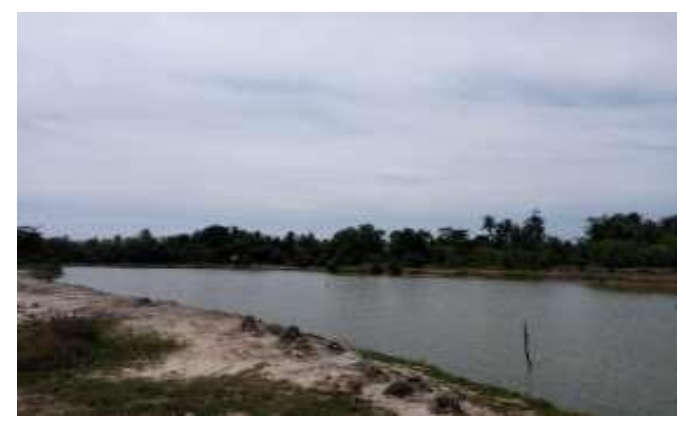

Gambar 2. Lokasi Tambak Desa Keutapang Mameh 


\section{Perencanaan rehabilitasi saluran irigasi tambak}

Teknik pelaksanaan dari program kerja ini seperti melakukan survey pada lokasi yang akan ditinjau, melakukan survey terhadap masyarakat sekitar untuk mencari informasi tentang program kerja yang akan dilakukan, dan melakukan perencanaan terhadap saluran irigasi tambak tersebut. Dalam pelaksanaan program kerja ini tidak ada bantuan dana dari desa sehingga program kerja ini hanya sebatas perencanaan dan tidak sampai ke tahap fisik (pembuatan).

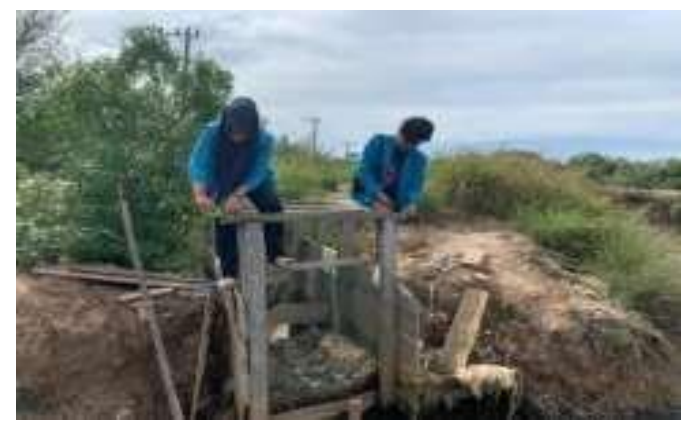

Gambar 3. Pengukuran Pintu Air Tambak

\section{Pembuatan Alat Pengolaan Air Baku Sederhana Dengan Sistem Filtrasi}

Untuk mendapatkan air bersih ada beberapa faktor yang harus diperhatikan, antara lain sebagai berikut.

a. Tingkat kecerahan air

b. Temperatur

c. TSS (Total Suspended Solid)

d. Salinitas

e. Derajat keasaman $(\mathrm{pH})$

f. Oksigen terlarut (DO)

g. Amonia

h. Fosfat

i. Nitrat

j. BOD (Biological Oxygen Demand)

k. COD (Chemical Oxygen Demand)

l. Timbal $(\mathrm{Pb})$

m. Klorofil

Air bersih penting bagi kehidupan manusia. di banyak tempat di dunia terjadi kekurangan persediaan air. Namun, masih terdapat beberapa daerah yang tidak dapat merasakan air bersih atau air baku yang layak digunakan, bahkan kekurangan persediaan air. Atas dasar inilah peserta KKNT membuat alat pengolahan air portable yang murah dan dengan mudah dioperasikan serta dapat dipindahkan ke tempat yang lain dengan harapan dapat membantu masyarakat. Kegiatan yang dilakukan adalah pembuatan alat pengolahan air baku sederhana menggunakan sistem filtrasi, yang dapat digunakan dalam skala kebutuhan rumah tangga.

\section{HASIL DAN PEMBAHASAN}

\subsection{Optimalisasi Pemanfaatan Hasil Laut untuk Peningkatan Ekonomi}

\section{Sosialisasi menumbuhkan plankton di tambak ikan sebagai pakan alami}

Kegiatan sosialisasi kepada masyarakat Desa Keutapang Mameh tentang Budidaya Plankton di Tambak dilaksanakan pada hari kelima KKN Tematik. Masyarakat Keutapang Mameh tidak menyukai jika diadakan sosialisasi di kantor Geuchik tersebut. Oleh karena itu, kami mengambil inisisatif melakukan kegiatan sosialisasi dengan cara mengunjungi para petani 
tambak masing - masing yang berada di tambak mereka. Kami mengunjungi salah satu petani tambak, petani tersebut memiliki tambak seluas $1000 \mathrm{~m}^{2}$ sebanyak 3 petak tambak.

Kami membawa bahan - bahan dasar pembuatan plankton dan juga membawa sampel yang sudah berhasil difermentasikan menjadi plankton. Kami memperkenalkan kepada para petani tambak mengenai bahan pembuatan fermentasi pada budidaya plankton di tambak serta proses fermentasi akan terjadi selama 3 hari setelah itu tumbuh menjadi plankton.

Masyarakat terutama para petani tambak sangat antusias dalam menanggapi sosialisasi tersebut dan hal ini dapat diketahui dengan beberapa pertanyaan dan keingintahuan masyarakat mengenai proses budidaya plankton di tambak dengan sistem yang ramah lingkungan, dengan bahan alami, murah dan juga sangat ekonomis. Masyarakat juga dapat mengaplikasikan hasil fermentasi plankton kepada tambak mereka dan juga mereka dapat memperkenalkan fermentasi plankton ini kepada para petani tambak lainnya.
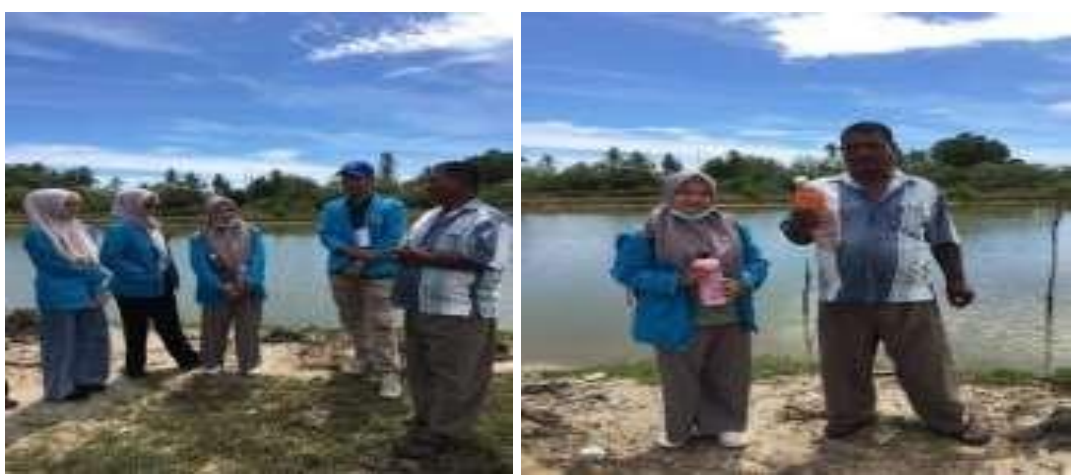

Gambar 4. Sosialisasi Cara Menumbuhkan Plankton kepada Petani Tambak

\section{Sosialisasi pengawetan ikan secara kimiawi dengan garam}

Desa Keutapang Mameh merupakan salah satu desa yang terletak di Kabupaten Aceh Timur yang memproduksi hasil laut berupa Ikan Kambing - Kambing (Canthidermis maculata) merupakan salah satu ikan demersal yang potensial. Potensi ini harus dimanfaatkan dengan maksimal mengingat kebutuhan konsumsi ikan semakin meningkat setiap tahunnya.

Kegiatan proses pengawetan ikan asin kepada petani tambak Desa Keutapang Mameh dilaksanakan pada hari kelima KKN Tematik. Kami mengunjungi para petani tambak dan juga melihat langsung proses pembuatan ikan asin, dimana ikan asin yang dihasilkan oleh Desa Keutapang Mameh yaitu ikan kambing - kambing dan ikan calang yang menjadikan ciri khas dari Desa tersebut. Kami memberikan pemahaman mengenai proses pengawetan ikan asin secara kimiawi dengan garam. Pembuatan ikan asin mengacu terhadap metode tradisional pembuatan ikan asin yang dilakukan oleh masyarakat Aceh.
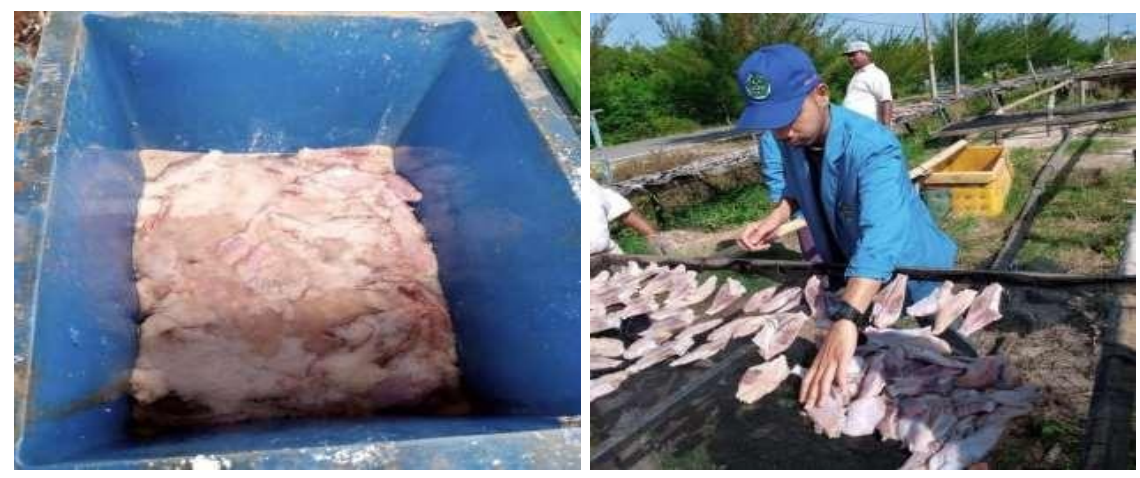

Gambar 5. Proses Pengawetan Ikan Asin

\section{Pelatihan pembuatan kerupuk ikan asin kepada masyarakat}

Desa Keutapang Mameh merupakan desa yang mayoritas penduduknya nelayan dan petani tambak sehingga dapat memproduksi ikan asin yang dapat diolah sebagai bahan baku 
pembuatan kerupuk ikan asin. Salah satu bahan baku kerupuk ikan asin adalah ikan kambing kambing (Abalistes stellaris). Ikan kambing - kambing adalah ikan laut yang belum dimanfaatkan secara optimal. Untuk menambah nilai tambah dari ikan tersebut maka diolah menjadi kerupuk ikan asin.

Ikan asin yang berasal dari ikan kambing - kambing ini pertama kali di terapkan di Desa Keutapang Mameh dikarenakan potensi hasil ikan laut yang dihasilkan yaitu ikan kambing kambing. Untuk itu, sangat disarankan agar produk ikan kambing - kambing dapat diterapkan oleh masyarakat yang berada di Aceh Timur.
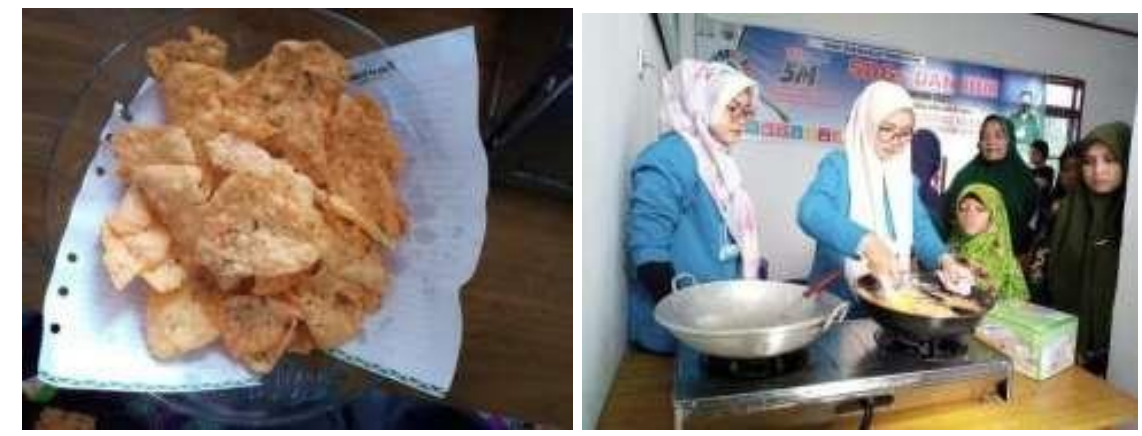

Gambar 6. Proses Pembuatan Kerupuk Ikan Asin

\subsection{Pengembangan Sarana Dan Prasarana Desa}

\section{Perencanaan rehabilitasi saluran irigasi tambak masyarakat desa}

Daerah irigasi tambak di Desa Keutapang Mameh, Kecamatan Idi Rayeuk, Aceh Timur merupakan salah satu wilayah tambak yang sering dimanfaatkan kegunaanya oleh masyarakat Desa Keutapang Mameh. Tambak merupakan salah satu aspek yang sangat penting untuk tempat di bagian pesisir, oleh karena itu perawatan saluran irigasi akan sangat perlu dilakukan untuk memperoleh hasil tambak dengan kualitas yang baik. Walaupun begitu produktifitas dari lahan ini masih belum optimal dikarenakan belum didukung oleh prasarana yang memadai seperti saluran irigasi yang dibuat tanpa perencanaan yang matang dan seadanya. Oleh karena itu mahasiswa Teknik sipil mencoba untuk meningkatkan produktifitas tambak dengan cara melakukan pengelolaan semi intensif, seperti melakukan penataan saluran irigasi tambak, perbaikan pintu air dan prasarana - prasarana lainnya. Dalam Program kerja ini akan dilakukan tahap pelaksanaan untuk rehabilitasi saluran irigasi tambak sebagai bagian dari proker yang akan direncanakan.

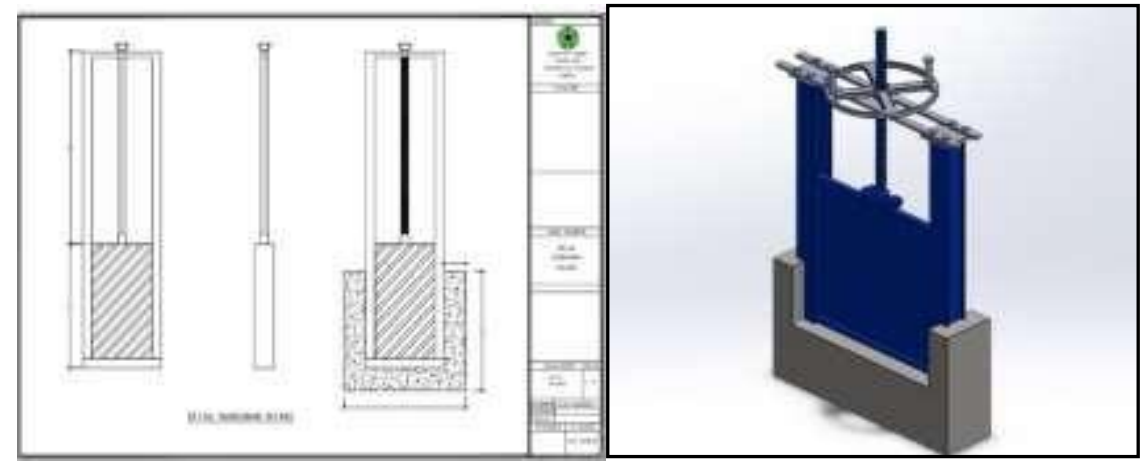

Gambar 7. Hasil Perencanaan Pintu Air Irigasi Tambak

\section{Sosialisasi pembuatan alat pengolahan air baku sederhana}

Kondisi fisik lingkungan perairan merupakan salah satu parameter yang digunakan sebagai pertimbangan dalam pengelolaan wilayah perairan. Ketepatan informasi kondisi fisik dapatmembantu formulasi pengelolaan wilayah pesisir dan pulau-pulau kecil yang tepat.

Desa Keutapang Mameh merupakan Desa yang bisa dibilang sangat sedikit kemungkinan untuk bisa mendapatkan kebutuhan air bersih, rata - rata masyarakat Desa Keutapang Mameh 
penggunaan air nya ialah air payau dengan kadar air $(\mathrm{pH})<7$ yang membuat air tersebut sangat tidak nyaman digunakan oleh pendatang. Oleh karena itu pada kegiatan KKN Tematik ini kami mahasiswa prodi Teknik Sipil berusaha untuk membuat alat filtrasi air untuk mendapatkan kadar air $(\mathrm{pH})=7$ untuk membuat air tersebut tidak terasa asam dan memiliki warna air yang bening.

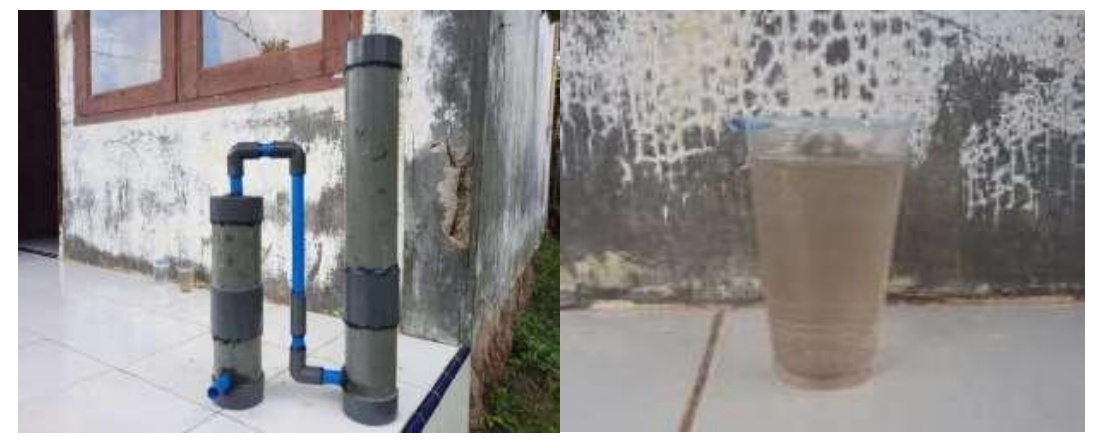

Gambar 8. Sampel Alat Filtrasi Air Baku

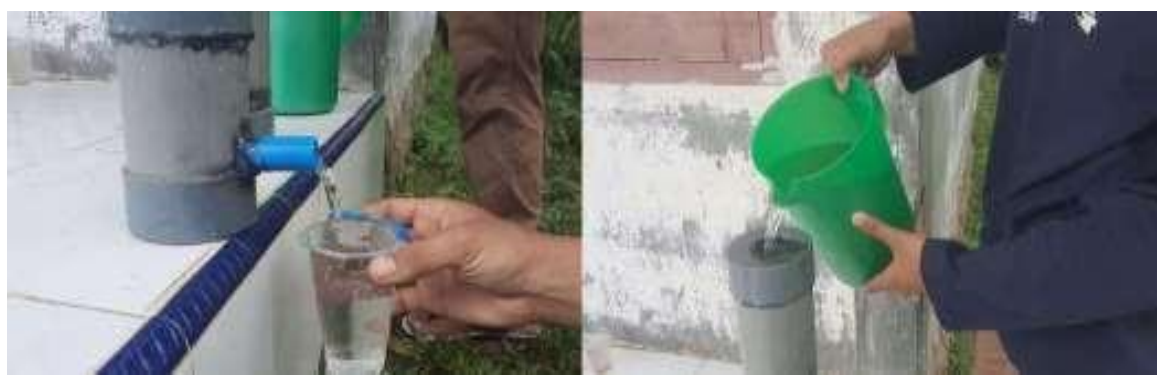

Gambar 9. Proses Penyaringan Air

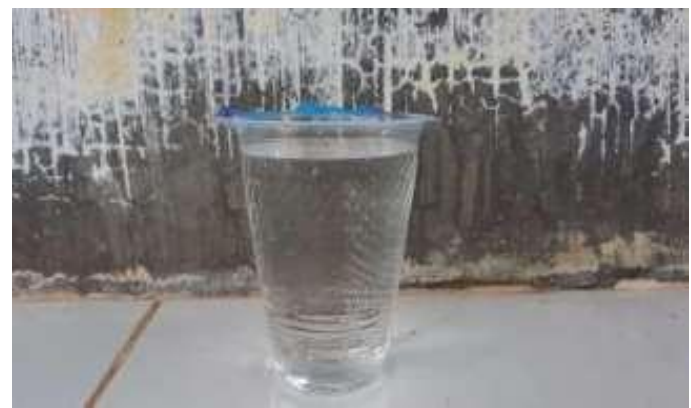

Gambar 10. Hasil Penyaringan Air

\section{Pembuatan website resmi desa}

Desa Keutapang Mameh merupakan salah satu desa yang berada di kecamatan Idi Rayeuk Kabupaten Aceh Timur. Di mana kebutuhan masyarakat untuk mendapatkan informasi sulit, data-data tentang desa belum mudah untuk didaptakan. Untuk membantu pembangunan/ pengembangan desa maka dibutuhkan sebuah sistem informasi terstrukturuntuk digunakan sebagai pendukung dalam pengembangan desa maupun masyarakat. Data desa merupakan data besar yang digunakan untuk sebuah acuan pengambilan kebijakan perangkat desa maupun sebagai data yang akurat untuk sebuah pertanggung jawaban perangkat desa maupun sebagai data yang akurat untuk sebuah pertanggung jawaban perangkat desa kepada masyarakat. Desa Keutapang mameh memiliki banyak data kependudukan, asset, potensi dan peta desa yang seharusnya bisa dikelola dan dikembangkan dengan maksimal sehingga dapat memberikan manfaat yang lebih bagi masyarakat. Kami ingin pengelolaan data kependudukan dengan terstruktur sehingga ketika ada penduduk yang pindah, meninggal, lahir dan sebagainya dapat di lihat tanpa harus membuka arsip kertas yang menumpuk. 


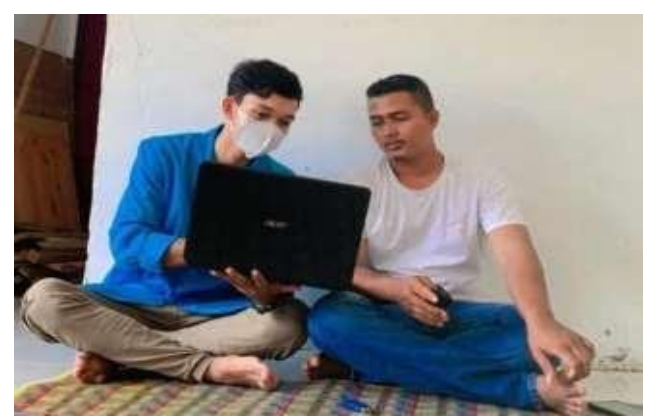

Gambar 11. Penyerahan Website Kepada Bapak Geuchik Desa Keutapang Mameh

Kerupuk Ikan Asin Merupakan Sebuah Produk Makanan Inovasi terbaru dari Desa Keutapang Mameh yang dimana berbahan Tepung Tapioka, Tepung Terigu dan Ikan Asin. Ikan Asin yang terkenal di Desa Keutapang Mameh itu sendiri banyak diminati oleh masyarakat setempat. Namun, karena terlalu sering Ikan Asin hanya dijadikan Lauk Pauk. Kami Mahasiswa KKN Tematik 2021 menyarankan Ide untuk pengolahan Ikan Asin menjadi Menarik dan Agar semakin banyak digemari oleh Masyarkat dan tak hanya masyarakat Setempat melainkan masyarakat luas yg berada di luar Desa Keutapang Mameh kecamatan Idi Rayeuk Kabupaten Aceh Timur. Oleh sebab itu kami mahasiswa KKN Tematik membuat web resmi Desa Keutapang Mameh untuk pemasaran kerupuk ikan asin agar kegiatan ini bisa berjalan dengan maksimal.

\section{KESIMPULAN}

Dalam pelaksanaan kegiatan KKN Tematik ini, mahasiswa KKN Tematik akan melakukan beberapa program yang akan dilaksanakan. kegiatan tersebut seperti : Melakukan gotong royong di Kantor Geuchik, Melakukan sosialisasi tambak ikan, Melakukan survei lokasi pengolahan Ikan Asin, Melakukan Kegiatan pengolahan Ikan Asin yang dilakukan Secara Langsung, Memberikan Pemahaman Mengenai Pengawetan Ikan Asin Kepada Petani Tambak, Melakukan Pembuatan Kerupuk Ikan Asin yang dilakukan Secara Tim, Mengaplikasikan Packaging Kerupuk Ikan Asin Kepada Masyarakat, Memberikan Resep Dan Kerupuk Ikan Asin Kepada Masyarakat Serta memberikan Web Aplikasi Penjualan Serta Pemasaran Penjualan Kerupuk Ikan Asin. KKN Tematik ini bertujuan Untuk Memberikan Serta Meningkatkan Potensi hasil Laut yang ada di Desa Keutapang Mameh, Salah Satunya adalah dengan memberikan cara olahan ikan Asin yang diolah menjadi sebuah produk makanana yaitu KERUPUK IKAN ASIN dan dapat meningkatkan perekonomian masyarakat yang ada di Desa Keutapang Mameh.

Dengan adanya KKN Tematik ini masyarakat di Desa Keutapang Mameh dapat lebih Berinovasi dalam meningkatkan Potensi Hasil Laut dan Juga meningkatkan Perekonomian Masyarakat setempat. Mahasiswa juga dapat belajar langsung di lapangan untuk menganalisa dan mengidentifikasi masalah serta menemukan solusinya.

\section{DAFTAR PUSTAKA}

Alfitri, N. (2016). Community Development Teori dan Apikasi. Yogyakarta: Pustaka Pelajar.

Badan Standarisasi Nasional. (2008). SNI 6774-2008 Tentang Tata Cara Perencanaan Unit Paket Instalasi Pengolahan Air. In B. S. Nasional, SNI 6774-2008 Tentang Tata Cara Perencanaan Unit Paket Instalasi Pengolahan Air (p. 1). Jakarta: Badan Standarisasi Nasional.

Daudy, M. H. (2015). Perwujudan Kedaulatan Laut di Aceh Berbasis Hak Ekonomi, Sosial dan Budaya Menurut Hukum Laut Internasional. Jurnal Hukum Samudra Keadilan, 59-67.

Dinas Kelautan dan Perikanan Aceh. (2019). Profil Usaha dan Investasi Kelautan dan Perikanan Provinsi Aceh. Aceh: Kementrian Kelautan dan Perikanan .

LPPM Universitas Nusa Putra. (2020). Buku Panduan Pengabdian Kepada Masyarakat Mahasiswa 2019/2020. Sukabumi: Universitas Nusa Putra. 
Mardikanto T., S. P. (2015). Pemberdayaan Masyarakat dalam Perspektif Kebijakan Publik. Yogyakarta: Alfabeta.

Margolang, N. (2018). PEMBERDAYAAN MASYARAKAT. Jurnal Agro Riau, 1-8.

Novia, A. A., Nadesya, A., Harliyanti, D. J., Ammar, M., \& Arbaningrum, R. (2019). Alat Pengolahan Air Baku Sederhana Dengan Sistem Filtrasi. Widyakala, 12-20.

Pradana, R. S. (2019). Kajian Komoditas Unggulan Perikanan Laut Tangkap Pada Setiap Kecamatan di Kabupaten Aceh Jaya. Agrica, 62-76.

Savitri, R., Amelia, R., \& Fahriani, F. (2016). Kuliah Kerja Nyata Tematik Upaya Pemberdayaan Masyarakat Dalam Penerapan Teknologi Tepat Guna Berbasis Lingkungan Dan Ekonomi Di Kecamatan Merawang Kabupaten Bangka Provinsi Kepulauan Bangka Belitung. 50-62. 


\section{Halaman Ini Dikosongkan}

